\title{
THE PLACE OF ISOTOPIC AGE DETERMINATIONS IN STRATIGRAPHY
}

by

William Compston

\begin{abstract}
Interest in stratigraphic applications of isotopic age determinations for the purpose of refining the geological time scale seems to have waned over the past fifteen years, at least amongst isotope geologists. This article points to some of the reasons for this and reappraises the role of numerical time in the definition of stratotypes in light of recent isotopic age determinations (especially fission-track) of volcanic horizons.
\end{abstract}

\section{troduction}

he IUGS Commission on Stratigraphy includes a ubcommission on Geochronology, comprising some ten iternational isotope geochronologists. Its function ssentially is to advise the Commission on matters pertaining to numerical geochronology. In recent years it has concerned itself with the unified presentation of isotopic ages by using standardized "best" values for the various radioactive decayconstants, and lately, it has also been considering what role it could take in promoting new isotopic work on the Phanerozoic time scale.

In August of 1978, the Fourth International Conference on Geochronology, Cosmochronology and Isotope Geology, held in Snowmass - at - Aspen, Colorado (U.S.A.), was attended by some 450 earth-scientists representing more than 20 different nations. It was as representative a group of isotope geologists as one could expect to find anywhere, and so the meeting provided a good opportunity for the Geochronology Subcommission to assess the current interest of geochronologists in stratigraphic applications.

The impressions and views that follow are strictly those of one member of the Subcommission. They are being aired chiefly to promote further discussion of time scale matters, and in particular, to seek a response from stratigraphers and palaeontologists who were not well represented at the Snowmass meeting.

\section{The Snowmass Time Scale Session}

One of the 20 different three-hour sessions of the Conference was entitled "Studies Related to the Phanerozoic", which is perhaps indicative of the Program Committee's estimation of the importance of the subject. My own feeling is that "one in twenty" as a measure of geochronologists who are interested in the Phanerozoic is probably an overestimate. In spite of this, the session itself proved stimulating, largely due to Ruben Ross' opening paper on fission-track dating of the British Silurian and Ordovician stratotypes; an outstanding and important contribution, it is given a special commentary in the next few sections.

None of the other papers in this session dealt with the Silurian or Ordovician, and only two were related to each other. One of the latter described the conflicting Ar age results for the KBS Tuff, of early hominid fame, the dating of which is a fascinating challenge for isotopic and other methods. Although each separate paper contributed new information to one or another part of the time scale, collectively they were distinctly incoherent and revealed the apparent paucity of new data that bears on any one period or theme within the Phanerozoic. This is said not as a criticism of the session but as a further demonstration of the current lack of interest in time scale work.
Fission-track dating of lower Palaeozoic volcanic ashes

The British stratotypes for the Silurian and Ordovician, like all other time-rock units in stratigraphy, are defined solely in terms of stratotypes related to the evolution of faunal assemblages. Detailed mapping and palaeontological study have shown that particular organisms are found only over narrow stratigraphic ranges, which are usually equated with narrow time-ranges, and this leads naturally to the definition of a "geological" time scale in terms of a succession of specified fossils. A "numerical" time scale could not be considered by stratigraphy's founding fathers because the isotopic techniques had not been developed for measuring the age of rocks.

Now, Ross et al. (1978) have shown that zircon from volcanic ash horizons within the Palaeozoic type-sections can be precisely dated by the fission-track method, so that a numerical time scale can be superimposed directly upon the geological scale. This is good fortune indeed, as it allows us

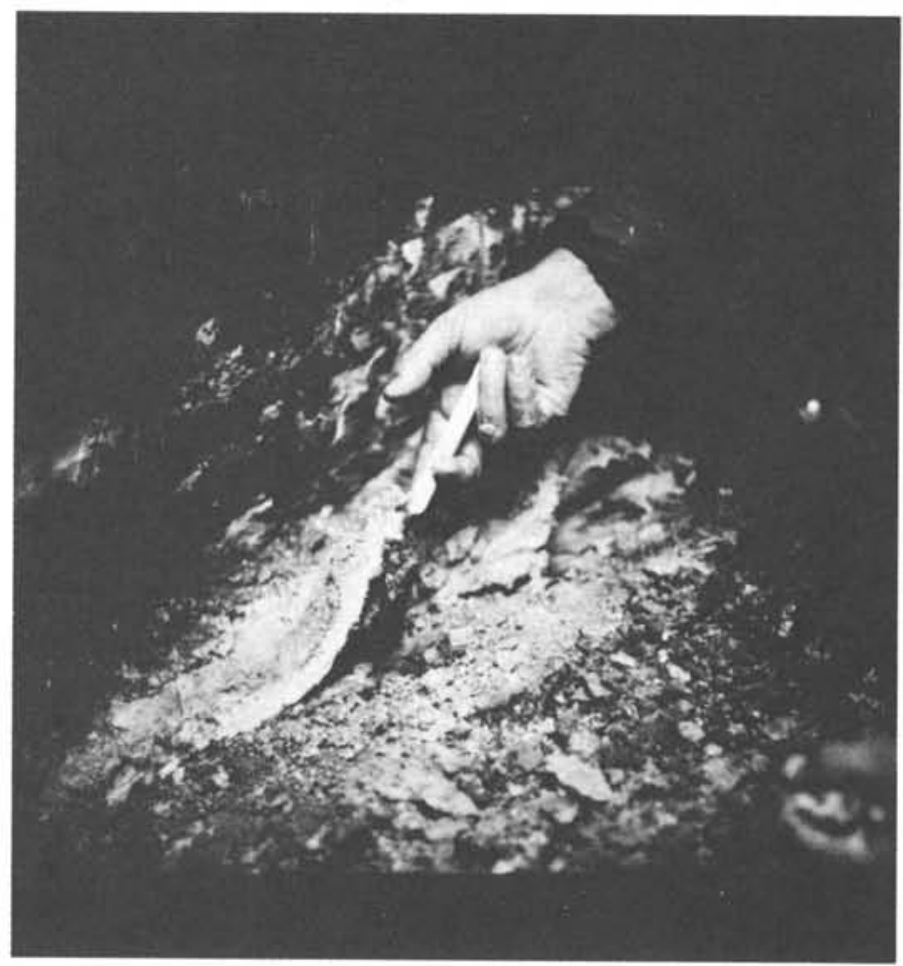

This Ordovician bentonite is the lower of a pair that crop out on the south bank of the Onny River (known sometimes as Jack Slither) in the U.K. Zircons in the lower bentonite and apatite in the higher one permitted the first dating of the 'Aeton Scott Beds in Murchison's type Caradoc in 1976. (Hands are those of G. Izett; Photo courtesy R.J. Ross, Jr.) 
to avoid the intermediate step of time-correlation between the type-sections and those sequences elsewhere that contain rocks the ages of which may be determined isotopically.

The Ross et al. fission-track time scale is completely in accord with the stratigraphic succession, has good internal precision and is in reasonable agreement with previous numerical estimates for the lower Palaeozoic (Table 1).

\section{TABLE 1}

ZIRCON FISSION-TRACK AGES FROM

ASH BEDS IN BAITISH TYPE SECTIONS

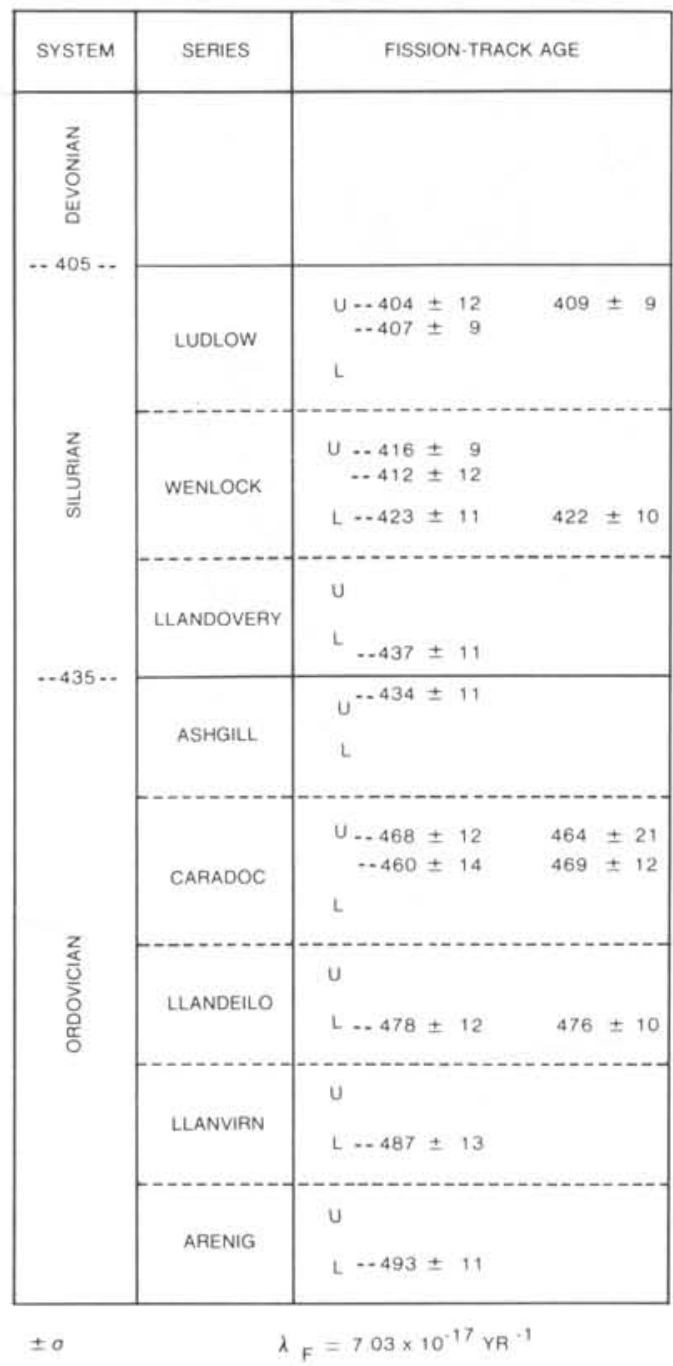

From Ross et al. (1978)

\section{Global time-correlations}

The Ross et al. discovery means that we can make the most direct possible age comparison between Silurian and Ordovician faunal assemblages throughout the world by way of the various isotopic methods. In principle, we can now test whether the occurrence of a particular fossil species is synchronous within well defined limits throughout its geographical range. The current precision of isotopic dating for favourable situations should allow time differences of only a few million years in the Palaeozoic to be detected with confidence. Certainly we have the expectation of synchroneity at this level of detection but it is important to confirm it.
The British Ordovician and Silurian stratotypes are comparatively thin sedimentary sequences in contrast to certain Palaeozoic sequences elsewhere. A second obvious application of Ross et al.'s work will be to examine the various rates of sedimentation and, when sufficient numerical ages have been accumulated, to settle the long-standing question of what period of time is represented by each stage.

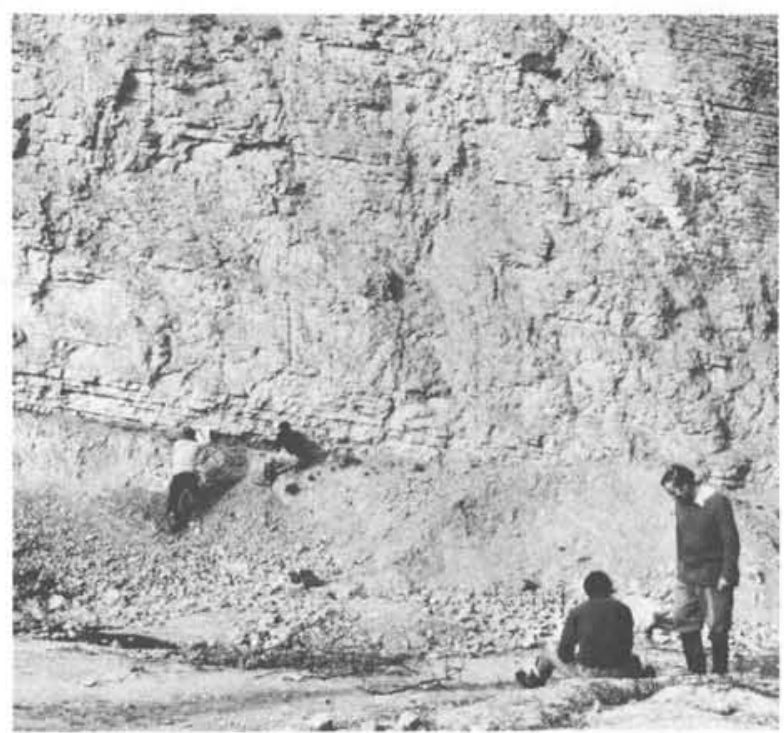

A prominent bentonite near the bottom of the Much Wenlock Limestone; this provided a date near the top of the Wenlock Series of $416 \pm 9 \mathrm{my}$. (Quarry on Wenlock Edge, Shropshire, U.K.; Photo courtesy R.J. Ross, Jr.)

\section{Comparison with other isotopic methods}

One of the realizations of the past ten years is that different isotopic methods may be systematically in error due to technical, as well as geological, problems. The most obvious of these is choice of decay-constant, and it was pleasing to observe that almost every contribution to the Conference employed the decay constants for $\mathrm{U}, \mathrm{K}$ and $\mathrm{Rb}$ as recommended two years ago by the Subcommission on Geochronology (Steiger and Jäger, 1977). These recommendations arose in part from close comparison of ages by different methods

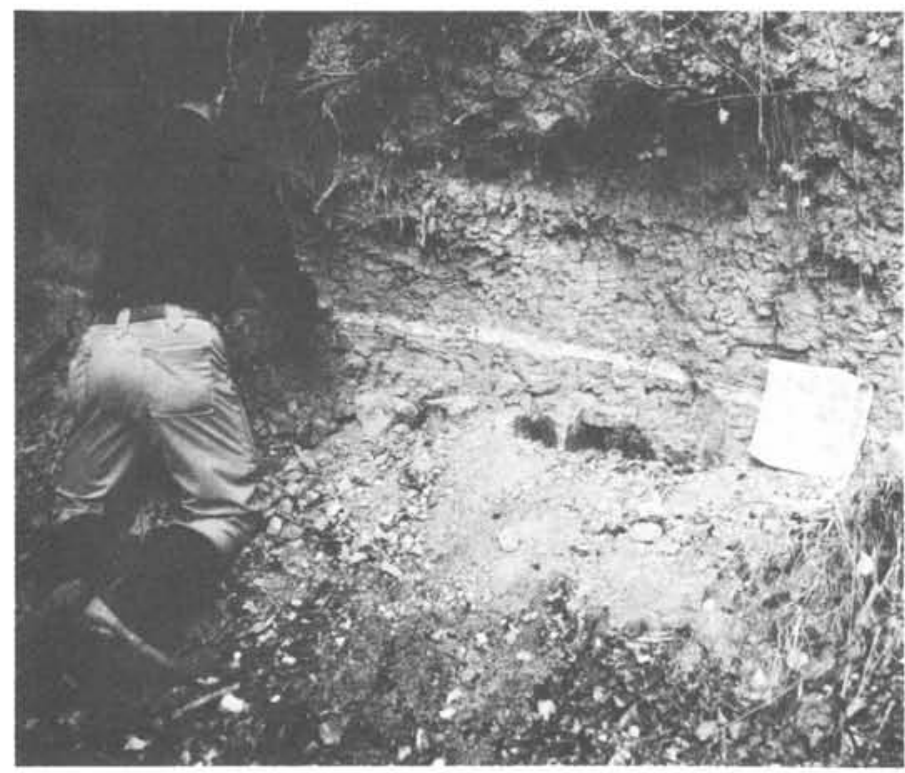

Sampling a bentonite from basal Buildwas beds, north bank of the River Severn, Shropshire, U.K. This sample produced a fission-track date of $422 \pm 10$ my for the base of the Wenlock Series. (Photo courtesy R.J. Ross, Jr.) 


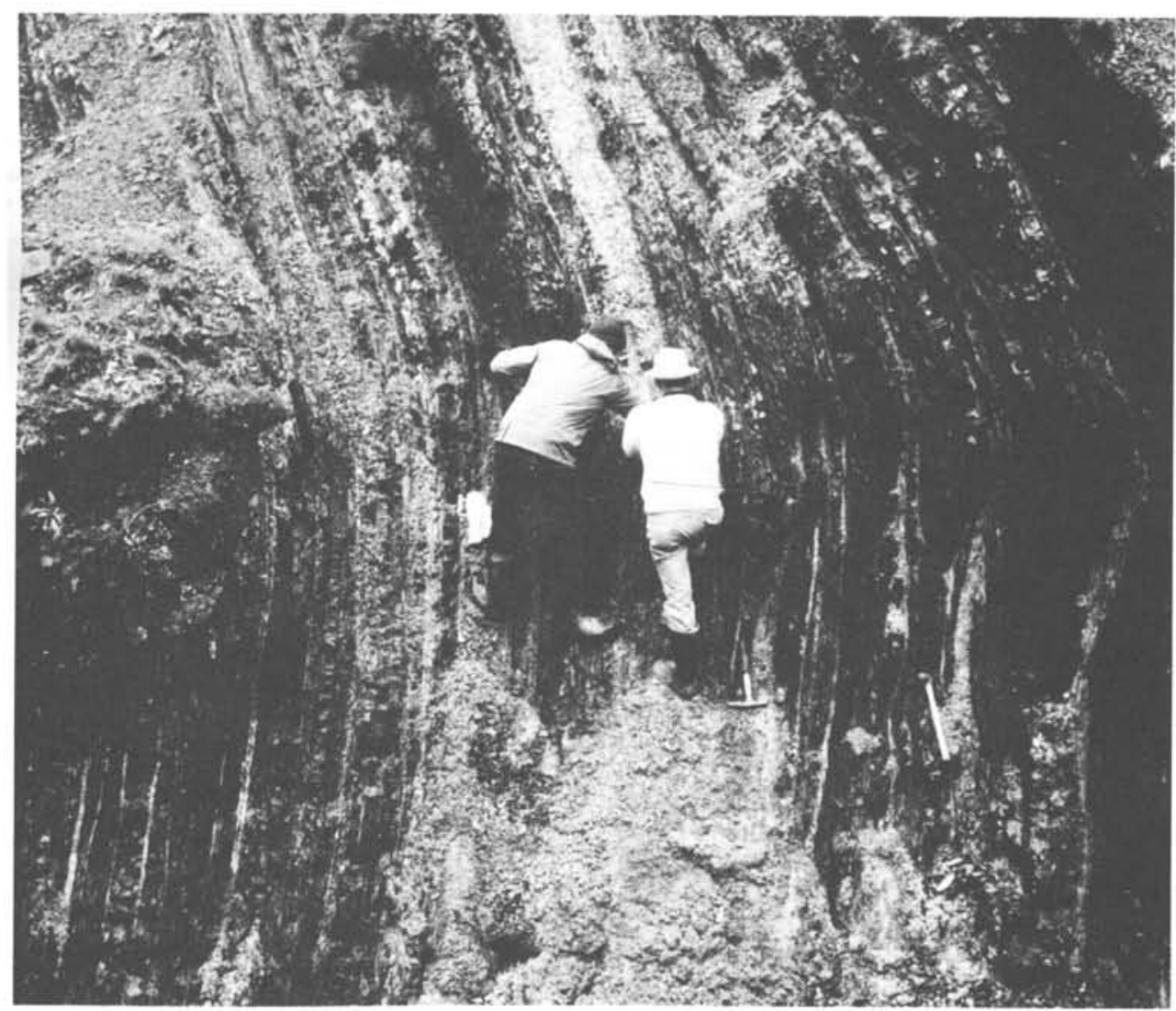

G. Izett and C.W. Naeser collect from the thick bentonite in the lower Birkhill Shale at Dobbs Linn, Moffat Water, in the Southern Uplands of Scotland. According to J.K. Ingham, this is the zone of $\underline{M}$. cyphus, low in the Llandovery. The resulting fission track date was $437 \pm 11$ my, which is very close to the data obtained by Lanphere and Churkin for the same graptolite zone in Alaska, using a different method. (Photo courtesy R.J. Ross, Jr.)

on the same rock unit. It is vital to expand comparisons with fission-track age determinations to ensure that Ross et al.'s time scale is not slightly biased in one way or another with regard to $\mathrm{Rb}-\mathrm{Sr}$ or $\mathrm{K}-\mathrm{Ar}$ ages; further comparisons of this type, already made extensive for Tertiary rocks, are now being planned.

It is interesting to note in passing, how the fission-track method for zircons by-passes a problem now identified in the orthodox $\mathrm{U}-\mathrm{Pb}$ method. This is the effect of the variable amounts of inherited radiogenic $\mathrm{Pb}$ that may be found in zircons (for example, Pidgeon and Johnson, 1974) which, if present, destroys the utility of such zircons for precise dating in the Phanerozoic. It is very likely that the Ordovician zircon ages used in earlier reconstructions of a numerical time scale are in error for this reason. By contrast, the low annealing temperature for fission tracks ensures that "inherited" ages never occur.

\section{Future isotopic studies of the Phanerozoic time scale}

The work of Ross et al. clearly illustrates the manner in which numerical time scale work has proceeded over the last decade. Essentially, it has been a random, individual and accidental progression. The possibility of using the ash beds in the British stratotypes arose through the chance discovery of their existence in the field by Ross himself, who was visiting the United Kingdom on other business, and through his realization (because of his association in the United States with fission-track expert C. Naeser) of their potential for fission-track dating. Sampling of the British stratotypes was then organized in a collaborative manner with stratigraphers, palaeontologists and isotope geologists.
Should this type of unplanned event be the normal method of progress in time scale work? The question was discussed informally at the Conference, the predominant response being that most isotope geologists were no longer interested in the geological time scale and saw little scope for "organized" research on the topic. A few would be willing to work on relevant well-documented and well-preserved rocks, provided that stratigraphers or palaeontologists could convince them of their importance. More, however, were fully committed to other research programs that were funded for different and more "fundamental" objectives. It was made plain that if stratigraphers believe numerical age measurements to be important for the Phanerozoic, they will have to sell this proposition to isotope geologists.

Aside from the correlation of sedimentary rocks, there are other reasons why a very precise numerical time scale for the Phanerozoic may be valuable. Geologists normally require the total geological history of an area, Phanerozoic or otherwise in age, as well as the time of sedimentation, and here isotopic methods may give numerical expression to metamorphic, structural and other events the ages of which cannot otherwise be measured with reasonable precision. From another viewpoint, there are some ambiguous or anomalous isotopic results which cannot be assessed properly unless a firm independent constraint can be placed on the age of igneous emplacement. For example, the occurrence of total-rock Rb-Sr isochrons that might be "too old" are of interest and concern to all geochronologists. Such a situation may be recognized if the igneous body in question is seen to thermally metamorphose sediments of accurately known numerical age, the latter thereby constituting an older limit to the age of emplacement. 
The role (or non-role) of isotope ages in the geological time scale

It is likely that isotopic age measurements will be the major means of correlating rock-units in the Precambrian. Are isotopic ages, then, really needed for Phanerozoic sediments, where correlations can be made more frequently and more sensitively on fossil evidence? This question becomes very pointed, from the viewpoint of isotope geologists, when it is realized that such vital time scale issues as the location of stratotype sequences and the definition of their boundaries are customarily resolved without any reference whatever to the possibility of measuring their numerical ages.

For example, McLaren (1977) has recently commented on the final report of the IUGS Silurian-Devonian Boundary Committee, which laboured for 12 years to recommend a type area, a type section and an horizon within the type section to define the boundary between the Silurian and Devonian Systems. The report appears to be admirably thorough and objective in its use of field and fossil evidence, but no consideration seems to have been given to the question of whether the boundary, or any part of the type section, was suitable for direct isotopic dating. If one of the possible candidates for the type section, for example, contained a number of tuff horizons (or even a single horizon near the defined boundary) capable of direct isotopic dating, should it not be preferred over the others because of its potential for direct comparison with a numerical scale?

The apparent omission of any such reasoning is either a tacit declaration that the numerical scale is not really important for Phanerozoic stratigraphy, or else it is a reflection of a serious lack of contact between stratigraphers and isotope geologists. The issue deserves prompt clarification, as it is relevant to the question of Precambrian time scale definitions. It would be too late to call in the isotope geologists after a Precambrian stratotype had been defined: the stratotype just might contain no horizons which can be dated.

\section{Conclusions}

Hard new facts are needed in every discipline and the numerical time scale is no exception: more discoveries of the Ross et al. type would be the best possible contribution to its definition. The apparent waning of interest in stratigraphic applications by isotope geologists may also reflect the failure of stratigraphers to recognize or bring forward newly found rock exposures that are both well-documented on the fossil time scale and capable also of accurate isotopic agedeterminations. Perhaps there are a number of such geological situations lying unexplored owing to lack of

\section{ABOUT THE AUTHOR:}

Professional Fellow at the Australian National University in Canberra and head of the isotope geology group in the University's Research School of Earth Sciences, Dr. William Compston is Chairman of the IUGS Subcommission on Geochronology. His current research interests are in Archaean geochronology and the dating of sedimentary rocks. A Fellow of the Australian Academy of Science, he is also an Honorary Fellow of the Geological Society of America. communication between stratigraphers and isotope geologists. If so, the initiative in these matters must come from the stratigraphers as it is from field geology that we obtain the first indication of a potentially valuable time scale application.

Orienting more new Ph.D. graduates toward the problem may also help, particularly if they are essentially "soft-rock" geologists but have also taken as an important part of their course, a practical education in one of the branches of isotope geochronology. To judge again by the Snowmass Conference, most of the isotope geology laboratories are producing graduates who deal with "hard rocks" and extraterrestrial rocks, and who employ isotopes in comparatively esoteric tracing applications rather that in "simple-minded" geochronology.

But above all, stratigraphers need to "sell" the scientific importance of numerical time scale work. They need to convince more isotope geologists of the need to direct their interests and research funds to stratigraphic applications; they should also engage them as early as possible in a project rather than at the end of one and as part-time consultants.

I thank my colleagues K.S.W. Campbell, R.W. Page and R.T. Pidgeon for their helpful discussions.

\section{References}

Pidgeon, R.T. and Johnson, M.R.W., 1974, A comparison of zircon $\mathrm{U}-\mathrm{Pb}$ and whole-rock $\mathrm{Rb}-\mathrm{Sr}$ systems in three phases of the Carn Chuinneag granite, northern Scotland: Earth Planet. Sci. Lett., 24, p. 105-112.

McLaren, D.J., 1977, The Silurian-Devonian Boundary Committee. A final report, in The Silurian Devonian Boundary: IUGS Series A, No. 5, E. Schweizerbart'sche Verlagsbuchhandlung, Stuttgart, 349p.

Steiger, R.H. and Jäger, E., 1977, Subcommission on Geochronology; convention on the use of decay-constants in geo- and cosmochronology: Earth Planet. Sci. Lett., 36, p. 359-362.

Ross, R.J. Jr., Naeser, C.W., Izett, G.A., Whittington, H.B., Hughes, C.P., Richards, R.B., Zalasiewicz, J., Sheldon, P.R., Jenkins, C.J., Cocks, L.R.M., Bassett, M.G., Toghill, P., Dean, W.T. and Ingham, J.K., 1978, Fission-track Dating of Lower Palaeozoic Volcanic Ashes in British Stratotypes. Short Papers of the Fourth International Conference on Geochronology, Cosmochronology, Isotope Geology: U.S. Geological Survey Open-File Report 78-701.

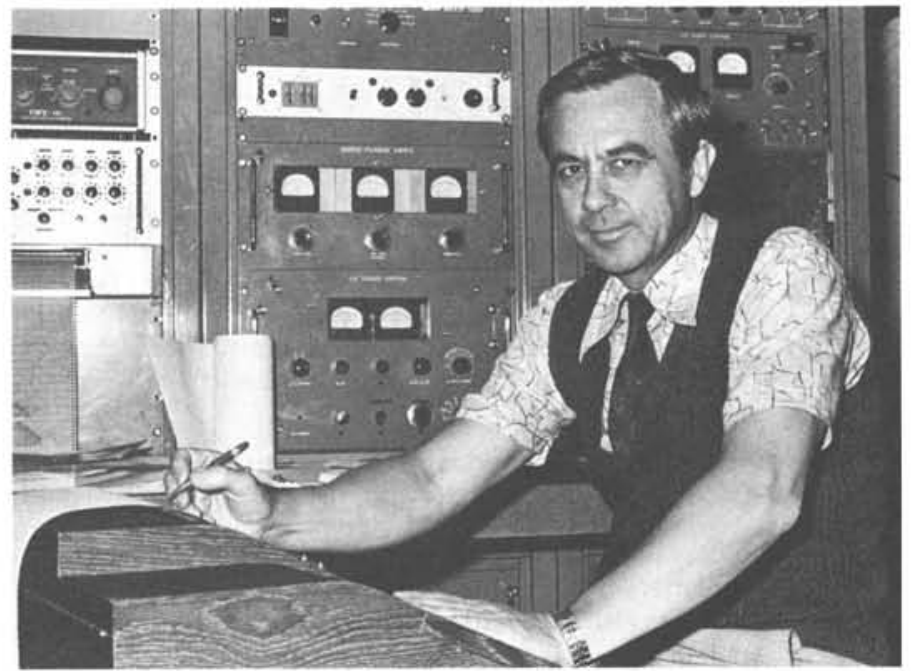

